\title{
TINGKAH LAKU AYAM KUB PADA PERBIBITAN AYAM KUB DI KABUPATEN SIGI, PROVINSI SULAWESI TENGAH
}

\author{
WARDI', M. DEWI ${ }^{1}$ DANA.B.L. ISHAK' \\ ${ }^{1}$ Balai Pengkajian Teknologi Pertanian Sulawesi Tengah \\ Jl. Poros Kulawi - Palu Km 23 No 62 Biromaru Sigi, Palu, Sulawesi Tengah \\ Email :wardiok1@gmail.com
}

\begin{abstract}
Native chicken is one of the livestock commonly breeding by the villagers because the breeding system does not require large inputs such as broiler chicken and has good environmental adaptability. Even in some places in the countryside, the breeding system is zero input. The information about the behavior of KUB chickens that are kept intensively in cages and freely is still very less. So, the study about the behavior of KUB chickens is needed in order to produce optimal. Behavior can represent the physiological conditions, feelings, and response of chicken towards changes environmental conditions. This study was conducted in one of the locations for the dissemination of KUB Chicken development in Sigi Regency, Central Sulawesi Province. The study used the one zero sampling method, observations were carried out in the morning (07.00-08.00 WITA) and afternoon (16.0017.00 WITA) for 7 days. The KUB chicken population that used in this study were 5 males and 25 females that were 18 weeks old. The result showed that the highest activity in the morning is; eating activity (10\%), drinking (9.9\%), perch (9.2\%), grooming $(9.2 \%)$ locomotion $(7.8 \%)$, agonistic $(1.7 \%)$, mating $(1,4 \%)$, elimination $(1.1)$, and rest $(1.1 \%)$, while the highest activity in the afternoon is eating $(11.8 \%)$, drinking $(9.9 \%)$, grooming $(8.6 \%)$, locomotion $(7.8 \%)$, perch $(7.0 \%)$, agonistic $(1,3 \%)$, elimination $(0.8 \%)$, rest $(0.8 \%)$, and mating $(0.6 \%)$. It was concluded that KUB chickens aged 18 weeks as a whole described behavioral behavior in order to fulfill their level of welfare in preparation for maximum production.
\end{abstract}

Keywords: Behavior, KUB Chicken, one zero sampling

\section{PENDAHULUAN}

Ayam kampung adalah salah satu ternak yang dipelihara oleh masyarakat desa secara umum karena sistem pemeliharaan tidak terlalu memerlukan input yang besar seperti ayam ras. Bahkan di beberapa tempat di pedesaan sistem pemeliharaannya zero input. Ayam kampung memiliki multifungsi yaitu sebagai hobi karena suaranya yang merdu, bahan upacara adat, ternak aduan dan penghasil daging dan telur (Sartika dan Iskandar, 2007). Menurut Iskandar et al., (1989) ayam kampung memiliki kemampuan adaptasi lingkungan yang baik di Indonesia, sehingga ayam ini banyak dipelihara secara semi intensif dan intensif di masyarakat.

Badan Litbang Pertanian sebagai penghasil produk unggulan pertanian (termasuk ternak), melalui Balitnak telah melakukan penelitian dan menghasilkan produk-produk ternak unggul, seperti ayam Kampung Unggul Balitbangtan (KUB) dengan keunggulan produksi telur tinggi yaitu produksi telur hen day $45-50 \%$, puncak produksi telur mencapai $84 \%$ pada umur ayam $31 \mathrm{minggu}$, bobot telur pertama bertelur $30 \mathrm{~g} /$ butir, dan akan bertambah terus sampai $36 \mathrm{~g} /$ butir pada akhir bulan kedua berproduksi (Sartika et al., 2013).

Peraturan Pemerintah Republik Indonesia No. 95 tahun 2012 tentang Kesejahteraan Masyarakat Veteriner dan Kesejahteraan Hewan Pasal 1 menyebutkan bahwa kesejahteraan hewan adalah segala urusan yang berhubungan dengan keadaan fisik dan mental hewan menurut ukuran perilaku alami hewan yang perlu diterapkan dan ditegakkan untuk melindungi hewan dari perlakuan setiap orang yang tidak layak teradap hewan yang dimanfaatkan manusia.

Kesejahteraan sangat berhubungan dengan terpenuhinya kebutuhan dasar mahluk hidup. Kesejahteraan unggas 
mencakup kesehatan fisik dan mental, karena itu memberi kesejahteraan pada unggas berarti memenuhi kebutuhan fisik dan mental unggas tersebut. Kesejahteraan sangat berpengaruh terhadap produktivitasnya (produktivitas unggas merupakan manifestasi dari pertumbuhan, perkembangan, produksi telur dan reproduksi) (Prayitno dan Sugiharto, 2015). Ewing et al. (1995) dalam Suryana dan Yasin (2013), membagi tingkah laku berdasarkan kebutuhan pokok yang bersifat naluri yaitu: makan, bereaksi, bergerak, mencari tempat hidup, berkelompok,berintorial,mempertahankan diri, bertelur, tidur dan istirahat.

Perilaku unggas adalah refleksi dari status kesejahteraan mereka pada saat tertentu, dan itu terkait dengan faktor internal (fisiologis) dan eksternal (lingkungan). Beberapa perilaku alami yang mendukung kesejahteraan, serta perilaku yang tidak diinginkan, dapat dirangsang oleh pengayaan lingkungan. Interpretasi yang benar dari perilaku yang diekspresikan oleh unggas, termasuk frekuensi, durasi, dan urutannya, dapat digunakan untuk memperkirakan kesejahteraannya (Costa et al., 2012).

Informasi tentang tingkah laku ayam KUB di kandang sangat minim sehingga diperlukan sebuah kajian tentang prilaku ayam KUB untuk mengetahui prilaku ayam agar tingkat kesejateraan terpenuhi sehingga dapat berproduksi maksimal.

\section{METODE PENELITIAN}

Kajian tingkah laku ayam KUB dilaksanakan di salah satu lokasi diseminasi pengembangan ayam KUB di wilayah desa Bulubente, kecamatan Dolo Selatan, Kabupaten Sigi, Provinsi Sulawesi Tengah.

Kajian dilaksanakan dengan mengunakan metode one zero sampling.
Nilai satu diberikan bila ada aktivitas yang dilakukan dan nol bila tidak ada aktivitas (Martin dan Batesson, 1988). Data diperoleh di analisis secara deskriptif. Peubah yang diamati meliputi aktivitas makan, minim, eliminasi (membuang kotoran), bertengger, lokomosi, agonistik, grooming, kawin dan istirahat pada setiap individu serta dihitung menggunakan rumus :

Persentase Aktivitas $=\mathrm{A} / \mathrm{B} \times 100 \%$

Ket :

A = Rata-rata nilai perilaku selama pengamatan

$\mathrm{B}=$ Total rata-rata nilai aktivitas perilaku selama pengamatan.

Pengamatan dilakukan pagi hari (07.0008.00 WITA) dan sore hari (16.00-17.00 WITA) selama 7 hari. Populasi ayam KUB yang digunakan untuk kajian ini sebanyak 5 ekor Jantan dan 25 ekor betina umur 18 minggu.

\section{HASIL DAN PEMBAHASAN}

\section{Keadaan Kondisi Kadang Ayam KUB di Desa Bolubete Kec Dolo Selatan Kab. Sigi}

Kondisi Kandang Inti Plasma Ayam KUB Balitbangtang terletak di Desa Bolubete, Kecamatan Dolo Selatan, Kabupaten Sigi. Rataan suhu selama kajian adalah sebesar $29^{\circ} \mathrm{C}$ (pagi), $33^{\circ} \mathrm{C}$ (siang) dan $29^{\circ} \mathrm{C}$ (sore). Terlihat pada Gambar 1 berikut ini. Rtaan kelembaban udara yang dicacat setiap pagi dan sore adalah masing-masing sebesar $82,15 \%$ dan 75,6\% . Kondisi suhu dan kelembaban yang tinggi akan berpengaruh terhadap kondisi dan aktivitas Ayam KUB.

\section{Perilaku Ayam KUB di Kandang Pembimbitan di desa Bulubete}

Beberapa aktivitas tingkah laku normal yang biasa dijumpai pada unggas, antara lain mandi debu (dust bathing), tingkah laku 
membuat sarang (nesting), tingkah laku bertengger (perching) dan berjalan (walking), tingkah laku mencoker-coker (scratching) serta tingkah laku agresif atau agonistik.

Tingkah laku ternak merupakan ekspresi suatu binatang yang disebabkan oleh semua faktor yang mempengaruhinya antara lain faktor ekternal dan internal yang akan mempengaruhi prilaku asli dan modifikasi. Aktivitas ayam KUB yang diamati terdiri dari dua macam, yaitu aktivitas yang berhubungan langsung dengan aktivitas makan (makan, minum, $\mathrm{BAB}$, dan bertenger) dan aktivitas yang memengaruhi aktivitas makan (lokomosi, grooming, kawin dan istirahat). Pengamatan dilakukan selama 7 hari di waktu pagi dan sore hari. Persentase aktivitas Ayam KUB selama pengamatan pada pagi hari ditunjukan pada Gambar 1.

\section{Prilaku Ayam KUB Pada Pagi Hari}

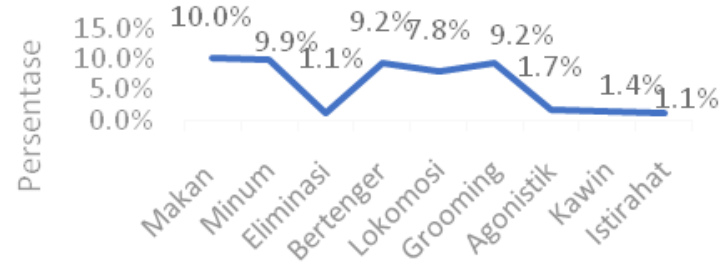

Aktivitas

Gambar 1. Persentase aktivitas ayam selama pengamatan.

\section{Makan}

Tingkah laku makan dipengaruhi oleh faktor genetik, suhu lingkungan, jenis makanan yang tersedia dan habitat (Warsono, 2002). Merujuk pada Gambar 1 memperlihatkan bahwa aktivitas prilaku ayam KUB terbesar adalah aktivitas makan sebesar 10\%. Berdasarkan laporan Sturkie (1986) bahwa ayam akan makan pada keadaan dingin dan tidak makan selama keadaan panas, karena kebutuhan energi yang lebih tinggi. Perilaku aktivitas ayam
KUB di pagi hari didominasi oleh aktivitas yang berpengaruh langsung terhadap aktivitas makan yang mendukung tingkat produktivitas Ayam KUB. Persentase aktivitas Ayam KUB selama pengamatan pada sore hari sebesar $11,1 \%$ ditunjukkan pada Gambar 2.

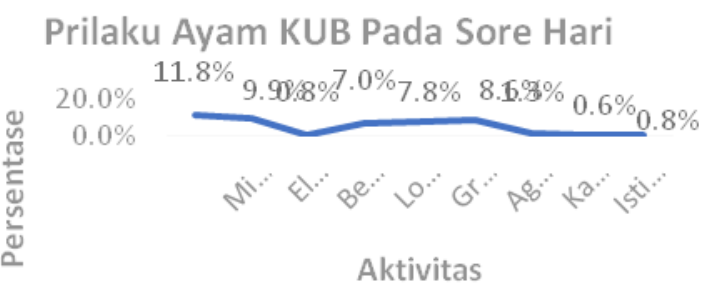

Gambar 2. Persentase aktivitas ayam selama pengamatan 
Begitu dengan aktivitas membuang kotoran jarang sekali ditemukan dikarenakan sering dilakukan pada menjelang pagi hari (dini hari). Jika terlihat pada siang hari itupun dalam keadaan stres karena ada gangguan dari luar kandang.

\section{Aktivitas yang mempengaruhi aktivitas makan Ayam KUB}

\section{Minum}

Perilaku minum pada ayam biasanya dilakukan sambil menenggelamkan paruh kedalam tempat minum, kemudian dalam selang beberapa detik ketika ayam meminum air biasanya ayam tersebut mengangkat kepala sambil membuka paruhnya (Mishra et al., 2005).

Aktivitas minum pada ayam KUB pada kandang relatif tinggi. Hal ini terlihat dalam persentase 9,9\% dari total aktivitas pada pagi hari. Menurut Nuriyasa (2003) fluktuasi penyinaran matahari juga akan memengaruhi iklim mikro dalam kandang ternak. Penyinaran matahari selama pengamatan dipagi hari dapat meningkatkan tingkat stres pada ayam KUB karena suhu udara dapat mencapai $29^{\circ} \mathrm{C}$. Pemeliharaan ayam KUB dengan suhu udara kandang yang lebih tinggi dari kebutuhan optimal akan menyebabkan ternak mengalami stres panas atau hipetermia. Untuk mengatasi kondisi tersebut ayam melakukan aktivitas minum untuk mengurangi stres panas.

Ayam KUB melakukan aktivitas minum, hal ini diduga kebutuhan air belum tercukupi dari bahan pakan yang diberikan. Keadaan seperti ini harus disediakan tempat minum di kandang dalam manajemen pemeliharaan Ayam KUB.

\section{Lokomosi}

Lokomosi adalah aktivitas pergerakan yang dilakukan dari suatu titik ke titik tertentu. Persentase akitivitas ini sebesar $7,8 \%$. Aktivitas ini biasanya dilakukan ketika ayam sedang melakukan aktivitas makan. Gambaran ini memperlihatkan bahwa ternak sangat menyukai wilayah yang luas, sehingga pada budidayaayam KUB memerlukan kandang yang sesuai dengan kebutuhannya.

Aktivitas lokomosi oleh ayam digunakan untuk mengeksplor lingkungan sekitarnya sehingga ayam dapat beradaptasi dengan lingkungan tersebut. Hal ini sejalan denganTandiabang (2014) menyatakan bahwa tingkah laku berjalan sering terlihat ketika ayam merasa terganggu dengan adanya keberadaan manusia dan ayam menjadi waspada.

\section{Grooming}

Grooming adalah aktivitas membersihkan diri atau merawat diri, seperti mematuk badan, mandi pasir litter alas kandang. Aktivitas grooming mempunyai nilai persentase yaitu sebesar 9,2\%. Aktivitas ini biasanya dilakukan ketika Ayam KUB sedang melakukan setelah makan pada pagi hari. Aktivitas grooming didominasi dengan mandi pasir dikandang. Sehingga dalam managemen pemeliharaan Ayam KUB sebaiknya dalam kandang disediakan pasir atau litter dalam kandang.

Aktivitas grooming pada pagi hari sangat tinggi yaitu sebesar $9,27 \%$ dari total keseluruhan aktivitas. Hal ini dikarenakan pada pagi hari ayam KUB diberi pakan sehingga setelah makan biasanya satwa tersebut melakukan grooming. Aktivitas ini akan turun pada sore hari menjadi 8,6\%, disebabkan sedang istirahat, dimana jarang melakukan grooming.

\section{Istirahat}

Menurut Mishra et al. (2005) tingkah laku ini biasa dilakukan ayam ketika dalam situasi yang sepi dan ayam biasanya 
istirahat lebih dari 2 menit. Aktivitas istirahat memperlihat persentase yang rendah yaitu sebesar $0,8 \%$ dari total aktivitas sore hari. Rendahnya persentase aktivitas istirahat bisa diakibatkan oleh suhu udara lingkungan sekitar. Suhu udara waktu sore hari sudah menurun $\left(30,8^{\circ} \mathrm{C}\right)$ akan menyebabkan ayam KUB masih aktif bergerak. Bozakova et al. (2012) menyatakan bahwa pengaruh suhu lingkungan yang tinggi dan peningkatan konsentrasi amonia menunjukkan semakin sering tindakan agresif dan jumlah makan, bertelur, membersihkan bulu, mandi debu yang rendah.

\section{Aktivitas Agonistik pada Ayam KUB}

Aktivitas agonistik adalah aktivitas dimana Ayam waspada dan siap menyerang sesama ayam. Aktivitas ini ditandai dengan ayam saling patuk mematuk dan kanibal terhadap ternak lain. Ayam KUB akan mengembangkan bulu sehingga seluruh tubuh terlihatan penuh dengan mengepak gepakan sayap. Selain itu ayam juga bertindak agresif dengan menyerang, selanjutnya siap menyerang dengan cara berusaha menancapkan taji kaki tajam ke dalam ayam yang lain.

Aktivitas agonistik mempunyai persentase sebesar $1,7 \%$ dari aktivitas total pada pagi hari. Hal ini menujukan bahwa ayam sedangan kompetisi merebutkan pakan yang diberikan ke kandang. Selain aktivitas diatas yang dilakukan ayam dalam tingkah laku hariannya ternyata masih ada aktivitas lain yaitu berusaha bertengger dan berusaha mengali alas kandang dengan cara mengais litter kandang. Aktivitas ini merupakan sifat ayam yang ada di alam liar, sehingga terkadang masih dilakukan didalam kadang. Sehingga dalam desain kandang ayam KUB dibuatkan tempat bertengger.

Tingkah laku agonistik adalah tingkah laku yang ditunjukkan oleh unggas untuk mempertahankan diri saat terjadi konflik sosial antar unggas. Secara umum, agonistic behaviour pada unggas melibatkan ancaman, agresi, penaklukan, usaha untuk menghindar dan kepasifan (sifat apatis). Dibandingkan dengan unggas betina, unggas jantan cenderung lebih memperlihatkan tingkah laku agonistik terutama terkait dengan usaha memperebutkan unggas betina untuk dikawini. Meskipun demikian, unggas betina juga menunjukkan tingkah laku agonistik pada kondisi tertentu, misalnya terkait dengan usaha untuk melindungi anaknya dan usaha memperebutkan pakan. Pada unggas yang dipelihara secara intensif, kanibalisme dapat menjadi masalah yang serius. Tingkah laku agonistik sering muncul pada kasus kanibalisme yang dapat diawali saling bertengkar dan patuk-mematuk untuk berebut pakan ataupun karena sifat bawaan (Prayitno dan Sugiharto, 2015).

\section{Bertengger}

Aktifitas bertengger termasuk dalam salah satu tingkah laku berlindung (shelter behavior). Pada umumnya ayam akan mencari perlindungan ketika merasa datangnya gangguan dari luar (lingkungan), seperti sinar matahari, angin, hujan, dan predator seperti serangga. Ayam akan naik ketempat yang lebih tinggi untuk bertengger. Umumnya ayam menyukai duduk dan berdiri di dekat tenggerannya.

Hubungan performa dengan tingkah laku bertengger biasanya tidak saling mempengaruhi satu sama lain (Mishra et al., 2005). Penyediaan tempat bertengger mengarah pada manfaat kesejahteraan dalam hal berkurangnya rasa takut dan agresi serta kondisi tubuh yang lebih baik (Donaldson dan O'Connell, 2012). Aktivitas bertengger memperlihat prosentase sebesar $7,0 \%$ dari total aktivitas sore hari. Dimana 
ayam masih melakukan aktivitas kegiataan menjelang senja hari.

\section{KESIMPULAN}

Aktivitas ayam KUB yang dominan adalah aktivitas makan dan minum baik pada pagi hari maupun sore hari sebesar $10 \%$ dan $11,8 \%$. Hal ini menunjukkan gambaran bahwa ayam KUB umur 18 minggu muncul perilaku tingkah laku demi memenuhi tingkat kesejahterannya untuk persiapan berproduksi secara maksimal.

\section{DAFTAR PUSTAKA}

Bozakova, N., S. Popova-Ralcheva, V. Sredkova, V.Gerzilov, S. Atanasova, A. Atanasov, Sotirov and N. Georgieva. 2012. Mathematical welfare assessment model of chicken breeder flocks. Bulgarian Journal of Agricultural Science. 18(2).

Costa, L.S., D.F. Pereira, L.G.F. Bueno and H. Pandorfi. 2012. Some Aspects of Chicken Behaviour and Welfare. Brazilian Journal of Poultry Science. 14(3).

Donaldson, C.J. and N.E. O'Connell. 2012. The influence of access to aerial perches on fearfulness, social behaviour and production parameters in free-range laying hens. Animal Behaviour Science. 142:1-2.

Iskandar S., B. Wibowo, E. Juarini, A.P. Sinurat danP. Sitorus. 1989. Budidaya Ayam Buras di Pedesaan. Pusat Penelitian dan Pengembangan Peternakan. Bogor.

Martin, P. dan P. Beteson. 1988. Measuring Behaviour, An Introduction Guide. $2^{\text {nd }}$ Ed. Cambridge University Press. London.

Mishra, A., P. Kaone, W. Schouten, B. Sprujit, P. Van Beek, dan J.H.M. Metz, 2005. Temporal and sequential structure of behaviour and facility usage of laying Hens In An Enriched Environment. Poult. Sci. 84:979-991.

Nuriyasa, M. 2003. Pengaruh tingkat kepadatan ternak dan kecepatan angin dalam kandang terhadap indeks ketidaknyamanan dan penampilan ayam pedaging.Majalah Ilmiah Peternakan. 5(3).

Prayitno, D.S. dan Sugiharto. 2015. Kesejahteraan dan Metode Penelitian Tingkah Laku Unggas. Universitas Diponegoro Press. Semarang.

Sartika, T. dan S. Iskandar. 2007. Mengenal plasma nutfah ayam Indonesia dan pemanfaatannya. Balai Penelitian Ternak. Bogor.

Sartika, T., S. Iskandar dan H. Zainal. 2013. Seleksi galur betina ayam KUB calon GP (Grand Parent).Laporan Penelitian Balai Penelitian Ternak No. Protokol : 1806.010.003/F-02/APBN-2014.

Sturkie, P.D. 1986. Avian Physiology. 5 th Ed. Editted by G.C. Whittow Academic Press. New York.

Suryana dan M. Yasin. 2013. Studi Tingkah Laku pada Itik Alabio (Anas platyrhynchos borneo) di Kalimantan Selatan. Seminar Nasional Inovasi Teknologi Pertanian.

Tandiabang, B. 2014. Tingkah Laku Ayam Ras Petelur Fase Layer yang Dipelihara dengan Sistem Free-Range pada Musim Kemarau. Fakultas Peternakan. Universitas Hasanuddin.

Warsono, I.U. 2002. Pola tingkah laku makan dan kawin burung kasuari (Casuarrius Sp.) dalam penangkaran di Taman Burung dan Taman AnggrekBiak. Makalah Pengantar Falsafah Sains.Program Pascasarjana. Institut Pertanian Bogor. Bogor. 